\title{
ANALISIS KINERJA PEGAWAI BADAN KEPEGAWAIAN DAERAH KABUPATEN WONOGIRI DITINJAU DARI KOMUNIKASI, KOMPETENSI DAN LINGKUNGAN KERJA
}

\author{
Yeni Trihastuti, Bambang Mursito, Eny Kustiyah \\ Fakultas Ekonomi Manajemen, Universitas Islam Batik Surakarta \\ Jl. KH. Agus Salim No.10 Surakarta \\ Email :yenith@yahoo.com
}

\begin{abstract}
The aim of this research are To find out the influences both simultaneously and partially of communication, competence, and work environment on the employee performance of the Wonogiri Regency Regional Personnel Agency. The population in this study were all employees at the Wonoguri Regency Regional Personnel Agency, which numbered 54 employees. The samples in this study were 54 respondents. Data collection techniques in this research were using observation, documentation, questionnaires, interview and literature study. Technical data analysis in this research were using classic assumption test, multiple linier test, $t$ test, $f$ test , the coefficients determined. The result of this study: There is a simultaneous and partially influence of communication, competence, and work environment on the employee performance of the Wonoguri Regency Regional Personnel Agency.
\end{abstract}

Key words : communication, competence, work environment, employee performance.

\section{PENDAHULUAN}

Kinerja pegawai sebagai hal yang sangat penting dan ini sebagai tantangan bagi Instansi dalam mengelola Sumber Daya Manusia. Pegawai dapat menjadi potensi bila dikelola dengan baik dan benar, tetapi akan menjadi beban apabila salah kelola (Prasetyo et.al, 2018). Suatu instansi tentunya mengharapkan pegawainya bekerja secara produktif, dengan pengaturan sumber daya manusia secara professional sehingga akan menciptakan kinerja pegawai yang berkualitas. Kinerja seorang pegawai merupakan hal yang bersifat individual, karena setiap individu memiliki kemampuan yang berbeda-beda didalam menyelesaikan pekerjaan (Posumo , 2013).

Dalam kinerja masing-masing pegawai tidak akan lepas dari komunikasi,kompetensi yang dimiliki oleh seorang pegawai dan keadaan lingkungan kerja dalam suatu instansi. Sebagian besar pribadi manusia terbentuk dari hasil integritas dengan sesamanya.

Aktivitas komunikasi diperkantoran senantiasa disertai dengan tujuan yang ingin dicapai. Pelaksanaan komunikasi yang tidak baik dapat mengganggu semua rencana, petunjuk, saran, instruksi, yang mengakibatkan pekerjaan menjadi kacau dan tujuan organisasi tidak tercapai. Oleh karena itu diperlukan adanya pelaksanaan dan penerapan komunikasi yang efektif yang dapat meningkatkan semangat dan kinerja pegawai.

Sumberdaya manusia yang mempunyai peranan yang sangat menentukan bagi pengembangan kualitas kerja disetiap organisasi. Mengingat kinerja mengandung komponen kompetensi dan produktifitas hasil, maka kinerja sangat tergantung pada tingkat kemampuan individu.

Pegawai dengan kompetensi baik dan sesuai, dapat memahami pekerjaan yang dikerjakan serta fungsi dirinya dalam menjalankan pekerjaan tersebut. Kompetensi yang dimiliki pegawai secara individual harus mampu mendukung pelaksanaan strategi organisasi 
dan perubahan suatu instansi. Semakin tinggi kompetensi maka kinerjapegawai akan semakin tinggi pula.

Lingkungan kerja tempat pegawai tersebut bekerja juga tidak kalah pentingnya di dalam meningkatkan kinerja pegawai. Kondisi kerja yang tercemar dapat menyebabkan pegawai mudah terserang penyakit, mudah stress, sulit berkonstrasi dan kurang produktif. Akan tetapi, lingkungan kerja yang segar, nyaman dan memenuhi standar kebutuhan layak akan memberikankontribusi terhadap kenyamanan pegawai dalam menjalankan pekerjaan.

Badan Kepegawaian Daerah (BKD) sebagai instansi yang memberikan pelayanan umum dibidang kepegawaian dan penyelenggara urusan pemerintahan pasti mempunyaibanyak tugas dan tanggungjawab yang harus dikerjakan. Untuk meningkatkan pelayanan terhadap masyarakat dibutuhkan kinerja pegawai yang baik. Banyak aktor yang dapat mempengaruhi kinerja pegawai diantaranya tidak tepat waktu dalam penyelesaian pekerjaan, pengaruh lingkungan, komunikasi dan kurangnya kompetensi .

Sehubungan dengan hal tersebut, maka penulis berpendapat layak untuk melakukan penelitian dengan judul: "Analisis Kinerja Pegawai Badan Kepegawaian Daerah Kabupaten Wonogiri ditinjau dari Komunikasi, Kompetensi dan Lingkungan Kerja

\section{TINJAUAN TEORITIS}

\section{Kinerja Pegawai}

Menurut Sedarmayanti (2017: 260) kinerja merupakan hasil kerja seseorang, sebuah proses manajemen atau suatu organisasi secara keseluruhan, dimana hasil kerja tersebut harus dapat ditunjukan buktinya secara konkrit dan dapat diukur

Menurut Mangkunegara (2007: 67) kinerja adalah hasil kerja secara kualitas dan kuantitas yang dicapai oleh seorang pegawai dalam melaksanakan tugasnya sesuai dengan tanggung jawab yang diberikan kepadanya.

Indicator kinerja pegawai:
a. Tujuan
b. Standar
c. Umpan Balik
d. Alat atau sarana
e. Kompetensi
f. Motif
g. Peluang

\section{Komunikasi}

Menurut Muhammad (2011: 7) Komunikasi adalah pertukaran pesan verbal maupun non verbal antara si pengirim dengan si penerima pesan untuk mengubah tingkah laku. Kemudian Handoko (2007: 56) komunikasi adalah proses pemindahan pengertian dalam bentuk gagasan atau informasi dariseseorang ke orang lain

Indikator komunikasi:
a. Keterbukaan ( openness )
b. Empati ( empathy )
c. Dukungan ( Support )
d. Rasa Positif ( Positiveness )
e. Kesamaan (Equality) 


\section{Kompetensi}

Kompetensi didefinisikan sebagai pengetahuan, ketrampilan, konsep diri dan keahlian yang melekat dalam dirinya sehingga dapat digunakan untuk memprediksi kinerjanya (Istiatin \& Dyah, 2016: 116). Menurut Wibowo (2016: 28) kompetensi menunjukan ketrampilan atau pengetahuan yang dicirikan oleh profesionalisme dalam suatu bidang tertentu sebagai sesuatu bidang yang terpenting dan sebagai unggulan.

Indikator kompetensi
a. Pengetahuan (knowledge)
b. Kemampuan (skills)
c. Sikap (attitude)

\section{Lingkungan Kerja}

Menurut Supandi (2013: 15) lingkungan instansi merupakan lingkungan disekitar pekerjaan yang mempengaruhi semanagt kerja setiap individu

\section{Kerangka Penelitian}

Untuk mempermudah pemahaman dan memperjelas penelitian maka dapat digambarkan suatu kerangka penelitian teoritis sebagai berikut:

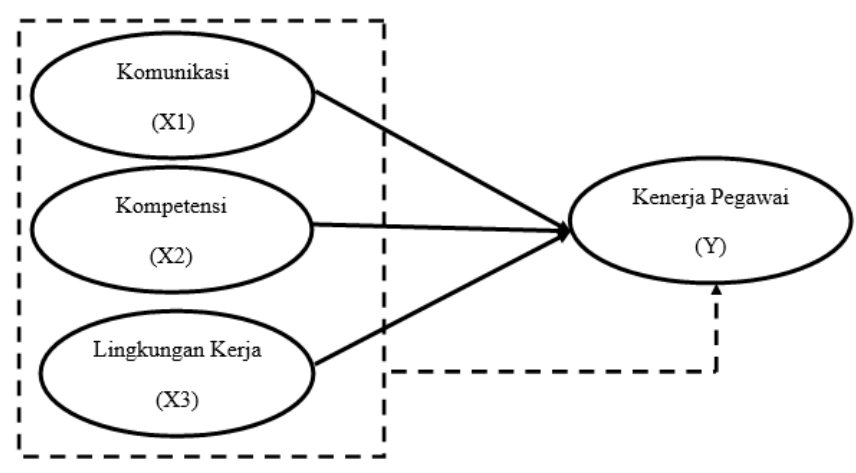

Penelitian ini dilakukan dengan mengambil obyek pada Badan Kepegawaian Daerah Wonogiri. Variabel yang diteliti dalam penelitian ini adalah komunikasi, kompetensi dan lingkungan kerja terhadap kinerja pegawai ..

\section{Hipotesa}

a. Diduga komunikasi, kompetensi, dan lingkungan kerja berpengaruh secara simultan dan signifikan terhadap kinerja pegawai di Badan Kepegawaian Daerah Kabupaten Wonogiri.

b. Diduga komunikasi berpengaruh positif dan signifikan terhadap kinerja pegawai Badan Kepegawaian Daerah Kabupaten Wonogiri

c. Diduga kompetensi berpengaruh positif dan signifikan terhadap kinerja pegawai Badan Kepegawaian Daerah Kabupaten Wonogiri.

d. Diduga lingkungan kerja berpengaruh positif dan signifikan terhadap kinerja pegawai di Badan Kepegawaian Daerah Kabupaten Wonogiri.

\section{METODE PENELITIAN}

\section{Populasi dan Sampel}

Populasi dalam penelitian ini adalah seluruh pegawai Badan Kepegawaian Daerah Kabupaten Wonogiri yang berjumlah 54 orang. Teknik pengambilan sampel dalam penelitian ini dengan menggunakan teknik non probability yaitu sampel jenuh atau sering disebut total sampling. 


\section{Metode Pengumpulan data}

Dalam penelitian ini, peneliti menggunakan beberapa metode, yaitu: observasi, dokumentasi , kuesioner, wawancara, dan studi pustaka.

\section{Model dan teknis Analisis}

Penelitian ini termasuk jenis penelitian kuantitatif yang dilakukan secara sistematis, terstruktur serat terperinci. Untuk menguji pengaruh variabel independen terhadap variabel dependen baik secara parsial maupun simultan menggunakan analisis regresi linear berganda. Berikut bentuk persamaan regresi dalam penelitian ini: ((Ghozali (2011: 17))

$\mathrm{Y}=\mathrm{a}+b_{1} X_{1}+b_{2} X_{2}+\mathrm{b}_{2} \mathrm{X}_{3}+\mathrm{e}$

Keterangan :

Y : kinerja pegawai

$\mathrm{b}_{0} \quad$ : konstanta

$\mathrm{b}_{1}, \mathrm{~b}_{2}, \mathrm{~b}_{3} \quad$ : nilai koefisien regresi

$\mathrm{X}_{1} \quad$ : komunikasi

$\mathrm{X}_{2} \quad$ : kompetensi

$\mathrm{X}_{3} \quad$ : lingkungan kerja

e : standar error

Selanjutnya dilakukan uji F, uji T, dan koefisien determinasi.

\section{Pengujian Hipotesis}

Untuk menguji hipotesis nomer 1 peneliti menggunakan uji F, Uji F digunakan untuk menguji koefisien regresi secara simultan atau bersama-sama antara variabel independen dengan variable dependen. Penilaian dengan melihat nilai Fhitung. Jika fhitung $<$ nilai $\mathrm{F}$ table, maka Hipotesis penelitian diterima. Dalam penelitian ini, hasil uji $\mathrm{F}$ menerangkan sejauh mana pengaruh bersama-sama komunikasi, kompetensi, dan lingkungan kerja terhadap kinerja pegawai. Untuk melihat besarnya kinerja pegawai menjalankan pekerjaan dapat dilihat dari besarnya koefisien determinasi. Kemudian, nilai thitung dilakukan untuk melihat pengaruh secara parsial antara variable independen terhadap variabel dependen. Penilaian dilihat dari nilai thitung. Jika nilai thitung lebih besar dari ttabel, maka hipotesis diterima.

\section{HASIL PENELITIAN DAN PEMBAHASAN}

Hasil perhitungan analisis regresi berganda dengan menggunakan SPSS 25 disajikan dalam tabel berikut:

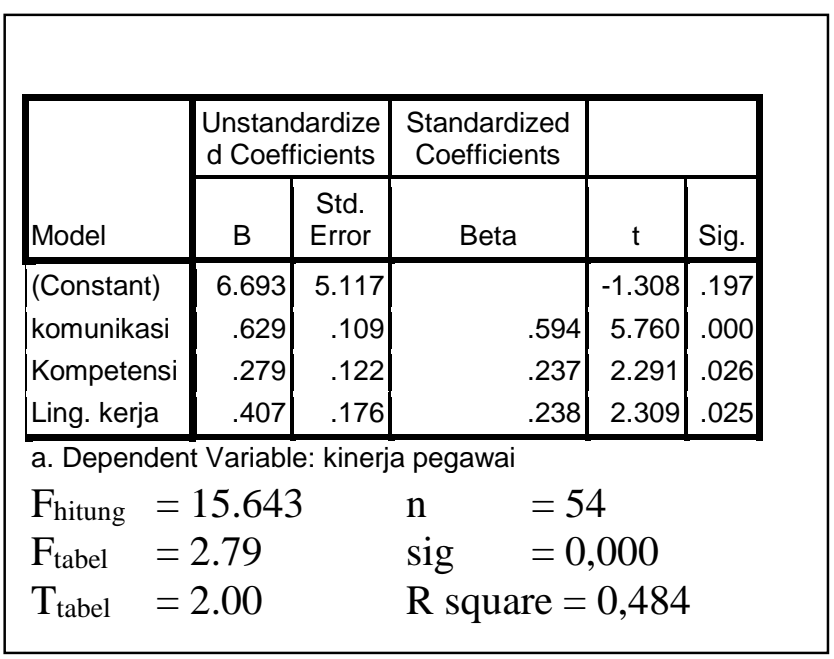


Sesuai dengan hasil analisis regresi linier berganda sebagai berikut :

$Y=6,693+0,629 X_{1}+0,279 X_{2}+0,407 X_{3}$

Hasil tersebut menunjukkan bahwa komunikasi, kompetensi, dan lingkungan kerja berpengaruh secara signifikan terhadap variabel kinerja pegawai di Badan Kepegawaian Daerah Kabupaten Wonogiri. Sedangkan dari hasil uji $t$ dapat diperoleh variabel komunikasi dengan nilai thitung $=5.760>\mathrm{t}_{\text {tabel }}=2.00$, maka Ho ditolak sehingga ada pengaruh yang signifikan komunikasi terhadap kinerja pegawai.

Variabel kompetensi dengan nilai $t_{\text {hitung }}=2.291>t_{\text {tabel }}=2.00$, maka Ho ditolak sehingga ada pengaruh yang signifikan kompetensi terhadap kinerja pegawai. Variabel lingkungan kerja dengan nilai $t_{\text {hitung }}=2.309>t_{\text {tabel }}=2.00$, maka Ho ditolak sehingga ada pengaruh yang signifikan lingkungan kerja terhadap kinerja pegawai.

Begitu juga dari hasil perhitungan uji $\mathrm{F}$ dapat diperoleh diperoleh nilai $\mathrm{F}_{\text {hitung }}=15.643>\mathrm{F}_{\text {tabel }}=$ 2.79, maka Ho ditolak sehingga secara bersama-sama ada pengaruh positif dan signifikan komunikasi, kompetensi, lingkangan kerja terhadap kinerja pegawai di Badan Kepegawaian Daerah Kabupaten Wonogiri .

\section{KESIMPULAN DAN SARAN}

\section{Kesimpulan}

a. Hasil uji F menunjukan komunikasi, kompetensi, dan lingkungan kerja secara simultan dan signifikan berpengaruh terhadap kinerja pegawai Badan Kepegawaian Daerah di Wonogiri .

b. Komunikasi berpengaruh positif dan signifikan terhadap kinerjapegawai pada Badan Kepegawaian Daerah di Kabupaten Wonogiri, yang ditunjukan dengan nilai thitung $=$ $5,760>t_{\text {tabel }}=2,00$, dengan nilai Sig $.=0,000$.

c. Kompetensi berpengaruh positif dan signifikan terhadap kinerja pegawai pada Badan Kepegawain Daerah di Kabupaten Wonogiri, yang ditunjukan dengan nilai $t_{\text {hitung }}=2,291>$ $\mathrm{t}_{\text {tabel }}=2,00$, dengan nilai Sig. $=0,026$.

d. Lingungan kerja berpengaruh positif dan signifikan terhadap kinerja pegawai Badan Kepegawaian Daerah di Kabupaten Wonogiri, yang ditunjukkan dengan nilai $\mathrm{t}_{\text {hitung }}=2,309$ $>t_{\text {tabel }}=2,00$, dengan nilai Sig. $=0,025$

\section{Saran}

Berdasarkan analisis dan kesimpulan, maka dapat disampaikan saran saran sebagai berikut :

a. Hasil analisis data menunjukkan adanya pengaruh yang signifikan antara Komunikasi, Kompetensi dan Lingkungan Kerja maka perlu diperhatikan dan perlu ditingkatkan lagi oleh Badan Kepegawaian Daerah di Kabupaten Wonogiri.

b. Untuk menjaga komunikasi yang selaras anatar pegawai, Badan Kepegawaian Daerah Kabupaten Wonogiri, perlu menjaga komunikasi danhubungan yang baik seperti selalu komunikatif sesama pegawai, menjaga kekeluargaan antar pegawai.

c. Badan Kepegawaian Daerah Kabupaten Wonogiri ,dalam usaha meningkatkan kualitas kinerja pegawai, maka instansi perlu memperhatikan Kompetensi, seperti selalu diadakan seminarpegawai, pelatihan dalam tiga bulan sekali. 


\section{DAFTAR PUSTAKA}

Ghozali, I. 2011. Aplikasi Analisis Multivariate Dengan Program SPSS. Semarang: Badan Penerbit Universitas Diponegoro.

Handoko, T. Hani. 2007. Manajemen Personalia Dan Sumber Daya Manusia (Edisi 2), Yogyakarta: Badan Penerbit Fakultas Ekonomi

Istiatin dan PW Diyah Aryati Ida. 2016, Modul Manajemen Sumber Daya Manusia Fungsi Operasional, FE-Uniba Surakarta.

Kuncoro, T. W., Sudarwati, S., \& Djumali, D. (2019). Pengaruh Kecerdasan Emosional, Kompetensi, Dan Motivasi Terhadap Kinerja Pegawai Setda Kabupaten Wonogiri. Jurnal Ilmiah Edunomika, 3(02).

Mangkunegara Prabu Anwar A.A. 2010. Manajemen Sumber Daya Manusia Perusahaan. Bandung: PT.Remaja Rosdakarya.

Muhammad, Arni. 2011. Komunikasi Organisasi. Jakarta : PT. Bumi Aksara

Prastyo, Hasiolan dan Warso. 2016. Pengaruh Motivasi, Kepuasan, dan Lingkungan Kerja terhadap Kinerja Karyawan Honorer Dinas Bina Marga Pengairan dan ESDM Kabupaten Jepara. Journal of Management. Vol. 02 No. 02

Sedarmayanti. 2017. Perencanaan dan Pengembangan Sumber Daya Manusia. Jakarta: PT. Bumi Aksara . 